\section{Listen to Andropov}

\section{Mr Yurii Andropov's views on arms control, unacceptable as yet, deserve close attention.}

ARMS control negotiations are necessarily like poker games. Even when the participants are more or less agreed on what would make an acceptable agreement (which rarely happens), they keep significant information up their sleeves and separately seek to push the basis of the negotiations in a direction that will give them some advantage, military or political. Mr Yurii Andropov's public statements in the past few weeks on the conduct of the parallel arms control negotiations at Geneva, in themselves a breach of the original agreement with the United States that the negotiations would be kept confidential, are part of the same poker game. By presenting himself to the world at large, but especially to the electorates of Western Europe, as a man of peace whose patience with the slow progress at Geneva has been exhausted, Mr Andropov will win friends both for himself and for the Soviet Union. Yet what he has to say is too interesting to be quickly dismissed. Governments in the West were in particular too quick to denounce Andropov's mid-December proposals on intermediate range nuclear missiles as unacceptable. They are that, but they are also a much better basis for negotiation than seemed likely only a few months ago.

The complexity of the Geneva process should not be underestimated. There are two ostensibly independent sets of negotiations under way, on nuclear weapons of intermediate range and on strategic weapons. Both negotiations are bilateral, between the United States and the Soviet Union, but the principals consult with their allies from time to time. The first set of negotiations is partly stimulated by the decision of NATO governments in 1979 that they would install intermediate range nuclear weapons in Europe beginning at the end of 1983 if before then they had not secured an acceptable agreement on the reduction of Soviet nuclear forces. The negotiations on strategic arms, on the other hand, are a continuation of previous bilateral negotiations, especially of the Strategic Arms Limitation Talks (SALT), made necessary by the undertakings the superpowers have given to others (for example, the members of the NonProliferation Treaty), by their own anxieties about the dangers (and the costs) of the strategic arms race - and made possible by President Reagan's belated acknowledgement, towards the end of his first year in office, that arms control negotiations were unavoidable. The two sets of negotiations are being conducted separately because they have different origins, but they are technically so closely linked that they must sooner or later be thrown together. It is, for example, unthinkable that the Soviet Union would settle for an agreed reduction of strategic missiles if other missiles capable of serving strategic purposes were simultaneously being installed in Western Europe. Mr Andropov, having broken his predecessor's vow of silence, might usefully have acknowledged that the Geneva process must eventually be all of a piece.

Although Andropov's proposals on intermediate weapons are, as described, unacceptable to the West, this does not imply that they are without merit. What he suggests is that the Soviet missiles which principally threaten Western European targets, the mobile SS20s, should be withdrawn out of range except for a force equivalent (in some sense) to the combined strengths of the British and French nuclear forces. In return, the United States would not go ahead with the supply of cruise and Pershing II missiles for bases in Western Europe.

The weakness of this proposal is that it would still leave in Soviet hands a dominant intermediate nuclear striking force represented by the substantial force of aircraft based in the Soviet Union. Moreover, the SS20 missiles, being mobile, could quickly be redeployed so as to threaten Europe, which is why the West at Geneva has been looking for verifiable destruction of missile stocks. The public Soviet admission that its large force of SS20 missiles is a cause for anxiety in Western Europe is nevertheless important. While this point has been emphasized by the United States behind the closed doors at Geneva, a public admission that it may be valid is worth seizing. Andropov's suggestion that the SS20 force might be reduced to match the French and British nuclear forces is more of a red herring. Both the British and French governments are mistaken in their assumption so far that their nuclear forces are irrelevant to the Geneva talks, but Andropov is wrong simply to lump them in with the intermediate nuclear weapons. Those carried by submarines, and whose accuracy is inherently less than that of land-based weapons, belong in the strategic talks under way at Geneva (which is another reason for throwing the two processes together).

Andropov's proposals on the reduction of strategic arms are more realistic. Limiting the numbers of strategic missiles held by the superpowers to 1,800 each would imply a reduction of about a quarter. Each side would be left with some 5,000 nuclear warheads, sufficient both for destroying the other in a final act of retaliation and, more significantly, for planning a first strike against the other's missile forces. Eventually, the objective in the SALT talks should be such a reduction of strategic forces that a first-strike attack is not feasible. It is probably too much to hope that either of the governments concerned would be able to go that far when they have so little recent experience to show that they can trust each other. Living with a 25 per cent reduction for a few years would moreover provide an opportunity for testing the efficacy of the procedures of verification on which the United States Senate is certain to spend much of its energy if some agreement eventually emerges from Geneva. To its credit, the United States Administration has in the past few days been more welcoming towards this Andropov proposal than towards what he had to say about intermediate weapons. The overriding snag is that the two sets of negotiations will have to be brought to a conclusion more or less together.

\section{What of development?}

\section{The Brandt Commission's second report should}

\section{reawaken compassion for the poor.}

As the long recession continues into another year, the prospects worsen for those developing countries which have for decades been the poorest in the world. Their capacity to fend for themselves has for the past five years been undermined by the slump in the prices of primary commodities, likely to continue while the recession lasts. The past few months have brought two further threats to their economic survival - the rash of protectionism that has affected industrialized countries, more concerned with the preservation of domestic jobs than with the capacity of the developing countries to eke out a living by the export of simple materials such as shoes and textiles, and by fears of instability in the international banking system. The poorest countries are not, of course, among the principal debtors of the banking system, which has principally been lending to countries such as Brazil and Mexico which seemed to have a chance, a few years ago, of breaking through to industrial prosperity. But now that the banking system has taken fright, the poorest countries will be less able than ever to hope that a commercial loan will help tide them over a crisis.

The recession apart, the steady deterioration of the poorest countries will bring trouble for the prosperous world. The need now is that the obligations of the industrialized world towards the poorest countries should be more widely understood. There will be an opportunity later this month, when the Brandt Commission is due to publish a second instalment of its continuing study of the problems of development. Although the commission is rightly concerned, at this stage, with difficulties such as those that have arisen in the banking system, its new report should rekindle interest in a daunting but important problem. While, in the short run, the plight of the poorest countries may be eased by the creation of more credit, ultimately there must be no escape from a more substantial transfer of resources from the prosperous to the needy. 